\title{
IDENTIFIKASI MOLEKULER BAKTERI ENDOFIT PENGHASIL L-ASPARAGINASE YANG DIISOLASI DARI MANGROVE BUTA-BUTA (Excoecaria agallocha)
}

\section{Molecular Identification of L-asparaginase-Producing Endophytic Bacteria Isolated from Mangrove Buta-Buta (Excoecaria agallocha)}

\author{
Asep Awaludin Prihanto ${ }^{1,2,3 *}$, Randy Fahrudin Ardiansyah', dan Ken Audia Pradarameswari² \\ 'Departemen Teknologi Hasil Perikanan, Fakultas Perikanan dan IImu Kelautan, Universitas Brawijaya. \\ Jl. Veteran Malang 65145, Jawa timur, Indonesia \\ 2BIO-SEAFOOD Research Unit, Fakultas Perikanan dan IImu Kelautan, Universitas Brawijaya. \\ Jl. Veteran Malang 65145, Jawa timur, Indonesia \\ ${ }^{3} \mathrm{Halal}$ Thoyib Research Center, Universitas Brawijaya, Jl. Veteran Malang 65145, East Java, Indonesia \\ *Korespondensi Penulis: asep_awa@ub.ac.id
}

Diterima: 3 Januari 2019; Direvisi: 2 Mei 2019; Disetujui: 17 Mei 2019

\begin{abstract}
ABSTRAK
L-asparaginase (EC 3.5.1.1) adalah enzim yang menghidrolisis asam amino L-asparagin menjadi amonia dan asam aspartat. Enzim ini mempunyai manfaat utama dalam bidang farmasi dan industri pangan. Enzim L-asparaginase tersebar secara luas pada mikroorganisme. Mikroorganisme yang mempunyai potensi menghasilkan enzim ini adalah mikroorganisme endofit dari tumbuhan mangrove. Penelitian ini bertujuan untuk mengisolasi dan mengidentifikasi bakteri endofit penghasil L-asparaginase dari tumbuhan mangrove Buta-buta ( $E$. agallocha). Skrining dilakukan dengan menggunakan medium selektif untuk mendapatkan bakteri penghasil enzim L-asparaginase. Identifikasi molekuler dilakukan dengan menggunakan analisis filogenetik berdasarkan data sekuen 16S rDNA. Dari hasil penelitian ini didapatkan lima isolat bakteri endofit penghasil enzim L-asparaginase, di mana isolat penghasil L-asparaginase tertinggi diidentifikasi secara molekuler. Hasil identifikasi filogenetik molekuler menunjukkan bahwa isolat kode D.104 teridentifikasi sebagai Enterobacter cloacae.
\end{abstract}

KATA KUNCI : L-asparaginase, mangrove Buta-buta, endofit, Enterobacter cloacae

\begin{abstract}
L-asparaginase (EC 3.5.1.1) is an enzyme which hydrolyze amino acid L-asparagine to aspartate and ammonia. Two main applications of this enzyme are in the pharmaceutical and food industries. The enzyme is widely distributed on microorganism. A potential source of Lasparaginase-producing bacteria is an endophytic bacteria from mangrove plant. This study aimed to isolate and identify L-asparaginase-producing endophytic bacteria from a mangrove plant, E. agallocha (Buta-buta). A screening was carried out using a selective medium to obtain the L-asparaginase enzyme producing bacteria. Molecular identification was carried out using phylogenetic analysis based on $16 S$ rDNA sequence data. In this study, five isolates of the Lasparaginase-producing endophytic bacteria were obtained. The molecular phylogenetic identification showed that the highest L-asparaginase-producing bacterial isolate (code D.104) was identified as Enterobacter cloacae.
\end{abstract}

KEYWORDS: L-asparaginase, mangrove Buta-buta, endophyte, Enterobacter cloacae

\section{PENDAHULUAN}

L-asparaginase mempunyai kemampuan untuk menghidrolisis L-asparagin menjadi amonia dan aspartat (Sanghvi et al., 2016). Enzim ini berpotensi untuk pengobatan leukemia limfoblastik akut (LLA) dan penyakit kanker lainnya (Shrivastava et al., 2016). L-asparaginase mengeksploitasi leukemia dengan menguraikan nutrisi yang dibutuhkan oleh sel leukemia yakni L-asparagin, sehingga pertumbuhannya terhambat bahkan terjadi kematian pada sel leukemia tersebut (Narta, Kanwar \& Azmi, 2007).

L-asparaginase dapat ditemui pada jaringan hewan, tumbuhan, serta mikroorganisme (bakteri, fungi, dan khamir) (Talluri, Bhavana, Kumar, \& Rajagopal, 2014). 
Bakteri adalah sumber L-asparaginase yang lebih baik dibandingkan dengan sumber lainnya, karena proses mengkultur bakteri lebih mudah sehingga proses ekstraksi dan pemurniannya lebih mudah dilakukan (Savitri, Asthana, \& Azmi, 2003). Bakteri yang pernah dilaporkan sebagai penghasil enzim L-asparaginase adalah Escherichia coli, Erwinia aroideae, Serratia marcescens, Pseudomonas aeruginosa, Citrobacter sp., dan Bacillus sp. (Kamble et al., 2012). Berbagai strain dari bakteri-bakteri tersebut merupakan bakteri endofit yang berasosiasi dengan berbagai jenis tumbuhan. Bakteri ini tidak mengganggu inangnya melainkan lebih meningkatkan pertumbuhan inangnya dan melindunginya dari serangan hama, penyakit dan kondisi lingkungan yang tidak menguntungkan (Joshi \& Kulkarni, 2004).

Tumbuhan mangrove mempunyai potensi sebagai inang bakteri endofit yang menghasilkan Lasparaginase. Menurut Duke (2011) mangrove adalah salah satu ekosistem pesisir yang dominan di dunia, terdiri dari pohon dan semak berbunga yang secara unik beradaptasi dengan kondisi pasang surut air laut. Lingkungan mangrove menurut Eldeen dan Effendy (2013), memiliki nutrisi yang baik bagi pertumbuhan kelompok bakteri tertentu, termasuk bakteri endofit yang berasosiasi dengan tumbuhan-tumbuhan di daerah mangrove. Interaksi endofit di bawah kondisi lingkungan mangrove ini dapat menyebabkan adaptasi khusus, termasuk menghasilkan metabolit-metabolit atau enzim-enzim yang penting bagi industri farmasi, pangan, dan industri berbasis bioteknologi lainnya. Kurniawan et al. (2018) melaporkan beberapa jenis bakteri potensial yang sukses diisolasi dari sedimen daerah mangrove seperti Bacillus pumilus, $B$. amyloliquefacien, B. alvei, B. coagulant, dan Pseudomonas sp. Penelitian ini bertujuan untuk melakukan isolasi, penapisan, dan identifikasi bakteri endofit penghasil L-asparaginase yang sangat penting bagi industri farmasi dan pangan.

\section{BAHAN DAN METODE}

\section{Bahan}

Bagian mangrove yang digunakan untuk sampel adalah batang, akar, dan daun tumbuhan mangrove Buta-buta (E. agallocha) yang diambil dari Pantai Bajulmati, Kecamatan Bantur, Kabupaten Malang (8²5'5301" LS, 112³8'801" BT). Bahan yang digunakan antara lain alkohol $70 \%$, garam natrium fisiologis steril 0,9\%, Luria Bertani Agar (LBA). Medium M9 modifikasi: agar bakteriologi, $\mathrm{NaCl}, \mathrm{L}-$ asparagin, D-glucose, $\mathrm{KH}_{2} \mathrm{PO}_{4}, \mathrm{Na}_{2} \mathrm{HPO}_{4}$, $\mathrm{MgSO}_{4} \cdot 7 \mathrm{H}_{2} \mathrm{O}, \mathrm{CaCl}_{2}$, Bromothymol blue.

\section{Metode}

\section{Pengambilan sampel}

Pengambilan sampel menggunakan metode Prihanto, Fatchiyah, Kartikaningsih, dan Pradarameswari, (2011) yang telah dimodifikasi. Beberapa bagian batang, akar, dan daun dari $E$. agallocha diambil secara acak dan dikemas di dalam plastik polyethylene, dan dibawa ke laboratorium. Sampel tersebut kemudian disimpan di dalam lemari pendingin dengan suhu $4^{\circ} \mathrm{C}$.

\section{Isolasi bakteri endofit}

Isolasi bakteri menggunakan metode Prihanto et al. (2011). Tiga bagian tumbuhan mangrove (akar, batang, dan daun) dipotong dengan cutter steril. Setiap sampel dimasukkan ke dalam kantong plastik dan diangkut ke laboraturium dalam box dengan suhu 4 ${ }^{\circ} \mathrm{C}$. Masing-masing bahan ditimbang sebanyak $1 \mathrm{~g}$ dan dilakukan pengenceran sampai koloni mudah untuk dihitung dan dipisahkan $\left(10^{-5}\right)$. Sampel sebanyak $1 \mathrm{~mL}$ ditanam dengan metode pour plate dan diinkubasi selama 72 jam pada suhu $35^{\circ} \mathrm{C}$. Koloni yang tumbuh dimurnikan pada media LBA. Selanjutnya biakan murni disimpan pada agar miring sampai digunakan untuk pengujian lanjut.

\section{Penapisan Bakteri Penghasil Enzim L-asparaginase}

Penapisan bakteri penghasil L-asparaginase dilakukan dengan menggunakan metode yang dijelaskan oleh Gulati, Saxena, dan Gupta, (1997). Aktivitas L-asparaginase diuji secara kualitatif berdasarkan pembentukan zona biru pada media M9 ditambahkan indikator Bromothymol blue (BTB) sebanyak $0,007 \mathrm{~g} / \mathrm{L}$. Selanjutnya $\mathrm{pH}$ medium diatur antara 5,5 sampai 6,5 . Zona biru yang terbentuk di sekitar koloni bakteri diamati setelah bakteri diinkubasi selama 24 jam pada suhu $35^{\circ} \mathrm{C}$. Pembentukan zona biru di sekitar koloni bakteri mengindikasikan adanya aktivitas ekstraseluler enzim L-asparaginase. Diameter zona biru diperoleh dari pengukuran dari tepi koloni yang tumbuh ke tepi zona biru pada media (Ashok et al., 2018). Pengukuran diulang sebanyak tiga kali untuk memastikan data konsisten. Isolat bakteri penghasil zona biru terbesar kemudian diidentifikasi secara molekuler.

\section{Pewarnaan gram}

Pewarnaan Gram bakteri dilakukan dengan mengacu kepada Hadioetomo (1983). Isolat bakteri ditempatkan di atas gelas objek, difiksasi dan ditetesi 
dengan larutan kristal violet (2 menit). Gelas objek dicuci dan dikeringkan. Preparat kemudian ditetesi yodium (2 menit), dicuci dan dikeringkan. Selanjutnya preparat ditetesi alkohol $95 \%$, sampai warna ungu menghilang, kemudian preparat dicuci dengan air mengalir dan dikeringanginkan. Preparat ditetesi safranin dan didiamkan selama 30 detik. Selanjutnya preparat dicuci dan dikeringkan.

\section{Identifikasi Bakteri Secara Molekuler Berdasarkan Sekuen 16s rDNA}

Identifikasi bakteri secara molekuler dilakukan berdasarkan metode yang dilakukan oleh Nursyam dan Prihanto (2018). DNA genom dari bakteri diamplifikasi menggunakan primer 27F (5'AGAGTTTGATCATGGCTCAG-3'), dan 1492R (5'TACGGCTACCTTGTTACGA-3'). Sampel DNA sebanyak $1 \mu \mathrm{L}$ dicampur dengan 18,5 $\mu \mathrm{L}$ Double Distillated Water (DDW), 2,5 $\mu \mathrm{L}$ Buffer $B$ dengan $\mathrm{Mg}^{2+}$ 10X, $1 \mu \mathrm{L}$ dNTPs, $1 \mu \mathrm{L}$ primer forward, $1 \mu \mathrm{L}$ primer reverse dan $0,2 \mu \mathrm{L}$ Taq polymerase. Reaksi dijalankan pada thermocycler (denaturasi: $94{ }^{\circ} \mathrm{C}, 45$ detik, penempelan: $61^{\circ} \mathrm{C}, 45$ detik, pemanjangan: $72{ }^{\circ} \mathrm{C}, 2$ menit). Proses amplifikasi dilakukan sebanyak 32 siklus. Hasil PCR dicek dengan teknik elektroforesis gel.

Hasil PCR dimurnikan menggunakan DNA extraction kit. Fragmen DNA murni ditambah larutan buffer Hi-DiTM Formamide (Genetic Analysis GradeApplied Biosystem), dilanjutkan dengan sekuensing menggunakan ABIPRISM ${ }^{\circledR} 310$ Genetic Analyzer. Hasil sekuen dianalisis menggunakan Basic Local Alignment Search Tool (BLAST) di situs http:// www.ncbi.nlm.nih.gov, analisis filogenetik dilakukan secara online dengan situs http://www.phylogeny.fr (Dereeper et al., 2008).

\section{HASIL DAN PEMBAHASAN}

\section{Isolasi Bakteri Endofit dan Penapisan Bakteri Penghasil Enzim L-asparaginase}

Sebanyak enam isolat bakteri endofit berhasil diisolasi dari tumbuhan E. agallocha. Dari keenam isolat yang diperoleh, pada umumnya berasal dari sampel batang. Hasil dari penapisan bakteri penghasil enzim L-asparaginase terhadap 6 isolat bakteri endofit menunjukkan bahwa 5 dari 6 isolat tersebut menghasilkan enzim L-asparaginase (Tabel 1). Penelitian serupa dilaporkan oleh Prihanto et al. (2018), bahwa 6 dari 12 isolat bakteri endofit mangrove Avicennia marina mensekresikan L-asparaginase. Menurut Mahajan, Saran, Saxena, dan Srivasta, (2013) L-asparaginase menghidrolisis asparagin menjadi asam L-aspartat dan amonia. Pelepasan amonia menyebabkan peningkatan $\mathrm{pH}$ medium. Pada pH asam BTB akan berwarna dan menjadi biru pada $\mathrm{pH}$ basa. Karena pembentukan amonia, $\mathrm{pH}$ filtrat kultur menjadi basa dan pewarna berubah warnanya menjadi biru. Pewarna BTB memberikan kontras warna yang tajam (biru tua dan kuning cerah) antara asparagin yang terhidrolisis dan yang tidak terhidrolisis.

Sampel yang memiliki zona aktivitas Lasparaginase paling lebar adalah isolat bakteri dengan kode D.104, sedangkan di sekitar isolat bakteri A.104 tidak menunjukkan adanya zona biru. Aktivitas enzim ditunjukkan dengan terbentuknya zona biru. Semakin lebar zona biru yang terbentuk, semakin tinggi aktivitas enzimnya sebagai akibat dari semakin banyaknya ammonia yang dihasilkan. Berdasarkan hasil tersebut, isolat D.104 memiliki zona yang paling lebar maka selanjutnya isolat ini diidentifikasi spesiesnya. Beberapa isolat bakteri dilaporkan menghasilkan L-asparaginase, yaitu isolat

Tabel 1. Hasil penapisan isolat bakteri penghasil enzim L-asparaginase

Table 1. The result of screening of $L$-asparaginase-producing bacteria

\begin{tabular}{ccc}
\hline $\begin{array}{c}\text { Kode bakteri/ } \\
\text { Bacterial code }\end{array}$ & $\begin{array}{c}\text { Asal Isolat/ } \\
\text { Isolate Origin }\end{array}$ & $\begin{array}{c}\text { Diameter zona biru/ } \\
\text { Blue-Zone Diameter } \\
(\mathbf{m m})\end{array}$ \\
\hline D.104 & Daun & $6.8 \pm 1.2$ \\
D.105 & Daun & $5.0 \pm 0.2$ \\
B.103 & Batang & $5.3 \pm 0.7$ \\
B.104 & Batang & $3.9 \pm 0.6$ \\
B.105 & Batang & $4.0 \pm 1.0$ \\
A.104 & Akar & - \\
\hline
\end{tabular}


Enterobacter sp. (Erva, Goswami, Suman, Vedanabhatla, \& Rajulapati, 2017), Escherichia coli, Erwinia chrysanthemi, Pseudomonas fluorescens (Cachumba et al., 2016), Erwinia carotovora, Proteus vulgaris, Sacharomyces cerevisiae, Streptomyces karnatakensis, Streptomyces venezuelae dan beberapa kelompok jamur seperti Aspergillus, Penicillium dan Fusarium (Sarquis, Oliveira, Santos, \& daCosta, 2004).

\section{Identifikasi Bakteri Secara Molekuler}

Hasil dari amplifikasi menggunakan metode PCR dan visualisasi menggunakan elektroforesis gel agarosa menunjukkan bahwa amplikon mempunyai ukuran sekitar 1600 bp (Gambar 1). Menurut
Nuroniyah dan Surya (2012), molekul fragmen gen 16S rRNA bakteri memiliki ukuran sekitar 1500 bp. Berdasarkan pernyataan tersebut dapat disimpulkan bahwa proses amplikasi fragmen gen $16 \mathrm{~S}$ rDNA isolat bakteri $\mathrm{D} .104$ berhasil dilakukan.

Penentuan spesies dilakukan dengan menggunakan analisis filogenetik. Hasil BLAST menunjukkan bahwa sekuen DNA dari isolat D.104 memiliki homologi yang tinggi dengan sekuen-sekuen E. cloacae (similaritas 99\%). Sekuen-sekuen homolog ini kemudian diunduh untuk dianalisis secara filogenetik (Gambar 2). Pohon filogenetik menunjukkan bahwa sekuen dari isolat D.104 (E. cloacae UB_B) berada satu klas dengan sekuen $E$. cloacaea strain YS60, E. cloacae strain IITRC14, dan E. cloacae

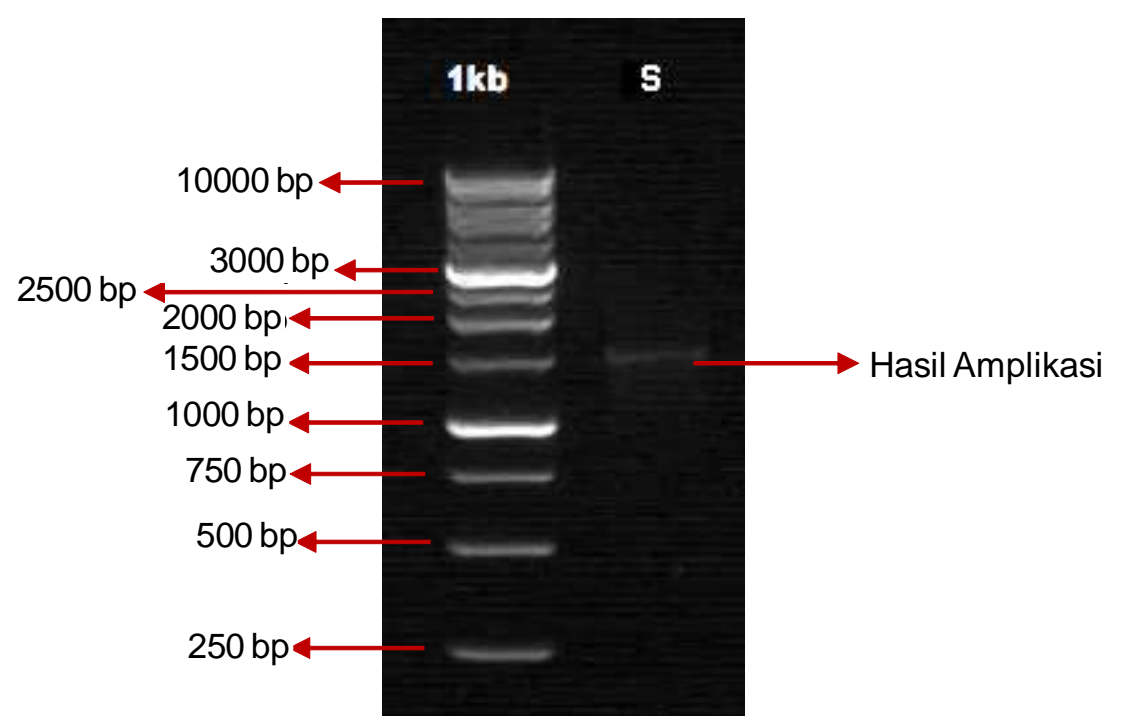

Gambar 1. Amplikon fragmen gen 16S rRNA dari isolat bakteri D.104 Figure 1. Amplicon of fragmen gen $16 S$ rRNA from D.104 bacteria isolate

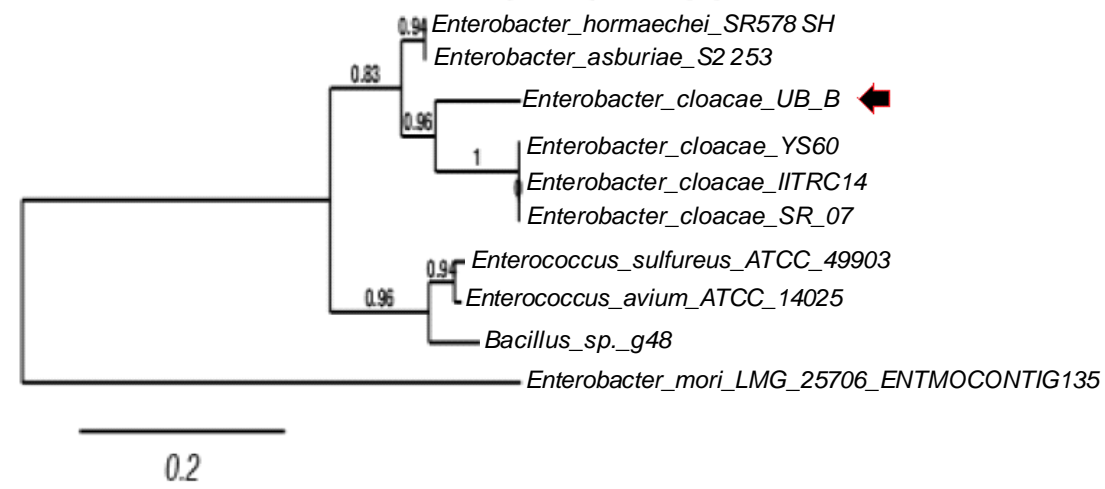

Gambar 2. Pohon filogenetik isolat D.104 (E. cloacae strain UB_B) Figure 2. Phylogenetic tree of D.104 isolate (E. cloacae strain UB_B) 


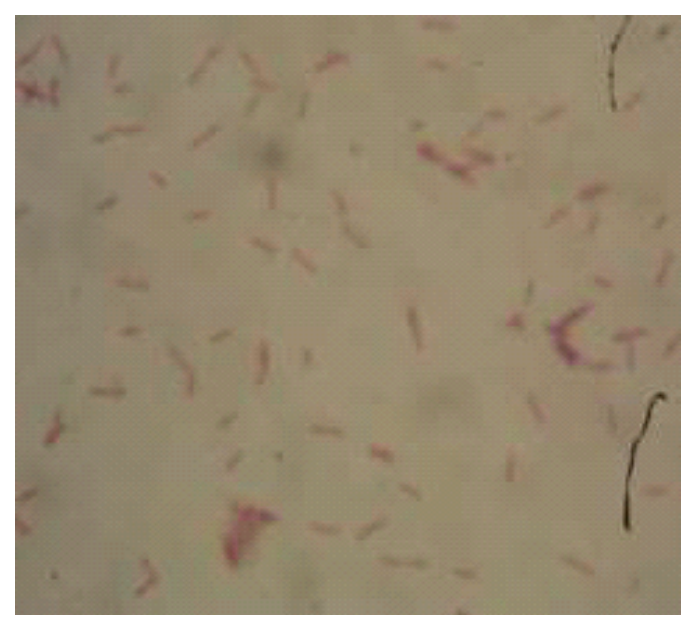

Gambar 3. Hasil pewarnaan E. cloacae UB_B Figure 3. Gram stain of E. cloacae UB_B

strain SR_07. Pewarnaan Gram mengindikasikan bahwa isolat D. 104 adalah Gram negatif dan berbentuk batang (Gambar 3). Hasil ini mendukung hasil identifikasi molekular yaitu isolat D.104 termasuk genus Enterobacter; sebagaimana dinyatakan oleh Humann et al. (2011) dan Mbai, Magiri, Matiru, \& Nyambati, (2013), bahwa Enterobacter merupakan bakteri Gram negatif yang memiliki morfologi berbentuk batang.

Bakteri telah dibuktikan sebagai alternatif penghasil L-asparaginase (Dalfard, 2016). Genus Enterobactermerupakan genus yang telah dilaporkan sebagai penghasil enzim L-asparaginase, seperti $E$. cloacae dan, E. aerogen dengan kemampuan bekerja pada substrat glutamin (Erva et al., 2017; Nawaz, Zhang, Khan, \& Cerniglia, 1998; Sharma \& Hussain, 2015). Enzim asparaginase yang dihasilkan oleh bakteri E. cloacae bekerja optimum pada $\mathrm{pH}$ dan suhu berturut-turut 7,0 dan $40^{\circ} \mathrm{C}$ (Sharma \& Hussain, 2015). Hasil tersebut berbeda dengan $L$-asparaginase dari $P$. geniculata, $P$. stutzeri, dan Aspergillus niger yang mampu hidup pada kondisi pH 9.0 (Hanaa \& Gamal, 2016). Bakteri Pseudomonas aeruginosa dari Avicennia marina juga dilaporkan menghasilkan Lasparaginase (Prihanto et al., 2018)

\section{KESIMPULAN}

Bakteri endofit yang berasosiasi dengan tumbuhan mangrove Buta-buta ( $E$. agallocha) dapat digunakan sebagai sumber isolat bakteri penghasil enzim Lasparaginase. Isolat bakteri penghasil enzim Lasparaginase tertinggi teridentifikasi secara molekuler sebagai Enterobacter cloacae.

\section{DAFTAR PUSTAKA}

Ashok, A., Kruthi, D., Jyothi, V. R., Asif, Q., Anoop, K. T. \& Devarai, S. K. (2018). Microbes Producing LAsparaginase free of glutaminase and urease isolated from extreme locations of antarctic soil and moss. Scientific Reports, 9, 1423. https://doi.org/ 10.1038/s41598-018-38094-1

Cachumba, J.G.M., Felipe A.F.A., Guilherme, F.D.P., Larissa, P.B., Júlio, C.D.S., \& Silvio, S.D.S. (2016). Current applications and different approaches for microbial L-asparaginase production. Brazilian Journal of Microbiology, 47, 77-85. http://dx.doi.org/ 10.1016/j.bjm.2016.10.004

Dalfard, A. B. (2016). L-asparaginase production in the Pseudomonas pseudocaligenes strain $\mathrm{JH}-71$ isolated from Jooshan Hot-Spring. Molecular Biology Research Communications, 5, 1-10. doi: 10.22099/ mbrc.2016.3379

Dereeper A, Guignon V., Blanc G., Audic S., Buffet S., Chevenet F., Dufayard J.F., Guindon S., Lefort V., Lescot M., Claverie J.M., \& Gascuel O. (2008). Phylogeny.fr: robust phylogenetic analysis for the nonspecialist. Nucleic Acids Res. 36: W465-W469. doi: 10.1093/nar/gkn180

Duke, N. C. (2011). Mangrove. In D. Hopley (ed.), Encyclopedia of modern coral reefs. structure, form and process (pp. 663). Dordrecht, Germany: Springer.

Eldeen, I. M. S., \& Effendy, M. A. W. (2013). Antimicrobial agents from mangrove plants and their endophytes. In A. Méndez-Vilas (ed.), Microbial pathogens and strategies for combating them: science, technology and education, 2, 872-882. Spain: Formatex Research Center.

Erva, R. R., Goswami, A. N., Suman, P., Vedanabhatla, R., \& Rajulapati, S. B. (2017). Optimization of Lasparaginase production from novel Enterobacter sp., by submerged fermentation using response 
surface methodology. Preparative Biochemistry and Biotechnology, 47(3), 219-228. doi:10.1080/ 10826068.2016.1201683

Gulati, R., Saxena, R. K., \& Gupta, R. A. (1997). Rapid plate assay for screening L-asparaginase producing microorganisms. Letters in Applied Microbiology, 24, 23-26.

Hadioetomo, R. S. (1993). Mikrobiologi dasar dalam praktek teknik dan prosedur dasar laboratorium. Jakarta: Gramedia.

Hanaa, H. B. \& Gamal, S. B. (2016). Optimization of growth conditions for purification and production of Lasparaginase by Spirulina maxima. Evidence-Based Complementary and Alternative Medicine, 1-7. doi:10.1155/2016/1785938

Humann, J. L., Wildung, M., Cheng, C., Lee, T., Stewart, J. E., Drew, J. C., Triplett, E. W., Main, D., \& Schroder, B.K. (2011). Complete genome of the onion pathogen Enterobacter cloacae ECWSU1. Standards in Genomic Sciences, 5, 279-286. doi: 10.4056/ sigs. 2174950

Joshi, M. R. D., \& Kulkarni, N. S. (2014). Isolation of Lasparaginase producing endophytic bacteria from plants recommended for cancer therapy. International Journal of Science and Research, 3, 506-509.

Kamble, K. D., Bidwe, P. R., Muley, V. Y., Kamble, L. H. Bhadange, D. G., \& Musaddiq, M. (2012). Characterization of $\mathrm{L}$-asparaginase producing bacteria from water, farm and saline soil. Bioscience Discovery, 3, 116-119.

Kurniawan, A., Prihanto, A. A., Sari, S. P., Febriyanti, D., Kurniawan, A., Sambah, A. B., \& Asriani, E. (2018). Isolation and Identification of cellulolytic bacteria from mangrove sediment in Bangka Island. IOP Conference Series: Earth and Environmental Science, 137, 012070. doi:10.1088/1755-1315/137/1/012070

Mahajan, R. V., Saran, S., Saxena, R. K., \& Srivasta, A. K. (2013). A rapid, efficient and sensitive plate assay for detection and screening of L-asparaginaseproducing microorganisms. FEMS Microbial Letter, 341(2), 122-6. doi: 10.1111/1574-6968.12100

Mbai, F. N., Magiri, E. N., Matiru, V. N., \& Nyambati, V. C. S. (2013). Isolation and characterisation of bacterial root endophytes with potential to enhance plant growth from kenyan basmati rice. American International Journal of Contemporary Research, 3, 25-40.

Narta, U. K., Kanwar, S. S., \& Azmi, W. (2007). Pharmacological and clinical evaluation of $\mathrm{L}$ asparaginase in the treatment of leukemia. Critical Reviews in Oncology/Hematology, 61, 208-221. doi: 10.1016/j.critrevonc.2006.07.009.

Nawaz, M. S., Zhang, D. A. A., Khan, C. E., \& Cerniglia. (1998). Isolation and characterization of Enterobacter cloacae capable of metabolizing asparagine. Applied Microbiology and Biotechnology. 50(5), 568-572. doi: $10.1007 / \mathrm{s} 002530051336$

Nuroniyah, T., \& Surya, R. P. (2012). Identifikasi spesies isoat bakteri s1 dengan metode analisa skuen fragamen gen 16S. Jurnal Teknik Pomits, 1, 1-6.

Nursyam, H., \& Prihanto, A. A. (2018). Identifikasi molekuler bakteri endofit mangrove Rhizopora mucronata penghasil gelatinase $\left(\mathrm{MMP}_{2}\right)$. Jurnal Pengolahan Hasil Perikanan Indonesia, 21(1),143147. doi: 10.17844/jphpi.v21i1.21537

Prihanto, A.A., Firdaus, M., \& Nurdiani, R. (2011). Endophytic fungi isolated from mangrove (Rhyzopora mucronata) and its antiobacterial activity on Staphylococcus aureus and Escherichia coli. Journal of Food and Engineering, 1, 386-389.

Prihanto. A. A., Fatchiyah, A., Kartikaningsih, H. dan Pradarameswari, K. A. (2018). Identifikasi Bakteri Endofit Mangrove Api-Api Putih (Avicennia marina) Penghasil Enzim L-asparaginase. Jurnal IImiah Perikanan dan Kelautan, 10(2),84-90. http://doi.org/ 10.20473/jipk.v10i2.10467

Sanghvi, G., Bhimani, K, Vaishnav, D., Oza, T., Dave, G., Kunjadia, P., \& Sheth, N. (2016). Mitigation of acrylamide by $\mathrm{L}$-asparaginase from Bacillus subtilis KDPS1 and analysis of degradation products by HPLC and HPTLC. Springer Plus, 5, 1-11. Doi: 10.1186/s40064-016-2159-8

Sarquis, M. I., Oliveira, E. M. M., Santos, A. S., \& daCosta, G. L. (2004). Production of L-asparaginase by filamentous fungi. MemlnstOswaldoCruz, 99, 489492 . Http://dx.doi.org/10.1590/S0074 02762004000500005 .

Savitri., N., Asthana, W., \& Azmi. (2003). Microbial Lasparaginase: a potent antitumour enzyme. Indian Journal of Biotechnology, 2, 184-194. Retrieved from https://www.researchgate.net/publication/285775631

Sharma, A., \& Hussain, I. (2015). Optimization of medium components for extracellular glutaminase free asparaginase from Enterobacter cloacae. International Journal of Current Microbiology and Applied Sciences, 4(1), 296-309.

Shrivastava, A., Khan, A. A., Khurshid, M., Kalam, M. A., Jain, S. K., \& Singhal, P. K. (2016). Recent developments in L-asparaginase discovery and its potential as anticancer agent. Critical Reviews in Oncology/Hematology, 100, 1-10. doi: 10.1016/ j.critrevonc.2015.01.002

Talluri, V. P., Bhavana, M., Kumar, M. M., \& Rajagopal, S. V. (2014). L-aspariganse: an ultimate anti-neoplastik enzyme. International Letters of Natural Sciences, 15, 23-35. doi:10.18052/www.scipress.com/ILNS.15.23 